\title{
Good Faith and Realpolitik. Approaching the Art of Politics of Lithuanian Rulers in the Fourteenth Century
}

Darius Baronas / darius.baronas@istorija.lt

Lietuvos istorijos institutas (Lithuanian Institute of History), Vilnius, LT

\begin{abstract}
This article deals with the issue of the Lithuanian conversion to Christianity in the 14th century by focusing on the art of politics of the Lithuanian rulers Gediminas (1316-1341), Algirdas (1345-1377) and Kęstutis (1381-1382) with regard to their Christian neighbours. The topic of intentional deception has been contextualised and given special attention in an attempt to highlight that the accession to Christendom was not a self-evident priority for Lithuanian rulers as long as they were beholden to a pagan-warrior lifestyle and were content with the inherited political situation vis-à-vis their Christian and Tatar neighbours.
\end{abstract}

\section{Keywords}

Lithuania; Papacy; Byzantium; Rus'; Tatars; Transcultural Communication 


\section{Towards a history of deception and misunderstandings}

Pagan Lithuania was a sui generis polity in late-medieval Europe. Sandwiched between East and West, between Greek Orthodox and Roman Catholic cultural circles, it belonged to neither. However, this was not a world unto itself, sealed off from its close and distant neighbours. The latter included not only Christians of both rites, but also pagan, and later, from the first half of the fourteenth century, the Muslim Tatars of the Golden Horde. ${ }^{1}$ It is commonly known that medieval Lithuania comprised vast swaths of territory of erstwhile Kievan Rus'. That is why it is called with good reason the Grand Duchy of Lithuania, even though the very name of this state was settled only at the end of the reign of Grand Duke Vytautas (1392-1430). ${ }^{2}$ The ruling class of this polity originated chiefly from the ethnic Lithuanian pagan heartland, where the Gediminid dynasty's foundations of power were located. ${ }^{3}$ The Ruthenian lands were additional building blocks for the Grand Duchy. They considerably surpassed the Lithuanian heartland in terms of territorial size and the overall number of the population. However, it must be kept in mind that square kilometres and population numbers did not translate as directly into political power as it would in the case of modern democratic societies. However, this simple observation has been lacking in the earlier, predominantly nineteenth-century Russian historiography, from which a number of avatars can be detected even today in some aspects of contemporary Belarusian historiography. ${ }^{4}$ This anachronistic approach is most often used in an attempt to place exclusive emphasis on the Orthodox aspect of the Grand Duchy by advancing suggestions that medieval Lithuania was in essence nothing more than another Russian dukedom or Belarusian state with a Lithuanian or Baltic admixture which, sooner or later, was doomed to dwindle and dissolve in a Slavic sea. ${ }^{5}$ Attention is brought to this purely teleological approach not from the desire to debunk some modern myths, but to demonstrate how easy it is, though by no means justified, to reduce complex historical reality to some modern shibboleths. It is necessary to remember that it is much more worthwhile to try to do justice to the historical record of the Grand Duchy of Lithuania by approaching this multi-faceted entity on its own terms and within the context of the thirteenth and fourteenth centuries. The pagan and Orthodox aspects of late-medieval Lithuania should thus be regarded as a kind of enigma, as a riddle inviting us to (de)construct it by using generally accepted research methods. At the

1 Rowell, Stephen C.: Lithuania Ascending: A Pagan Empire within East-Central Europe, 1295-1345. Cambridge 1994; Baronas, Darius - Rowell, Stephen C.: The Conversion of Lithuania: From Pagan Barbarians to Late Medieval Christians. Vilnius 2015.

2 Adamus, Jan: O tytule panujacego i państwa litewskiego pare spostrzeżeń. Kwartalnik Historyczny 44, 1930, pp. 330-332.

3 Gudavičıus, Edvardas: Lietuvos istorija. Vol. 1. Nuo seniausiu laiku iki 1569 metu. Vilnius 1999, pp. 70-83; Baronas, Darius - Dubonis, Artūras - Petrauskas, Rimvydas: Lietuvos istorija. Vol. 3. XIII a. - 1385 m. Valstybès iškilimas tarp Rytu ir Vakaru. Vilnius 2011, pp. 334-361, 407-422.

4 Baronas, D. - Rowell, S. C.: The Conversion, p. 65 with references to further literature.

5 Even though such visions are not confined to Russian historiography, they largely derive from it. Cf. e. g. Paszkiewicz, Henryk: Początki Rusi. Ed. Krzysztof Stopka. Kraków 1996, pp. 226, 246 and 275; DvorNik, Francis: The Slavs in European History and Civilization. New Brunswick 1962, p. 216. 
same time, we have to be clear that the dual pagan-Orthodox nature of the Lithuanian state in the fourteenth century appears exceptional only in the context of East-Central Europe. If we switch our view to Eastern Europe and Central Asia, then the Lithuanian polity becomes much less exotic. It was not unusual to find Orthodox and pagan populations living side by side in the immense swaths of land stretching from Samarkand in the East to Pera on the Bosphorus in the West. ${ }^{6}$

From the outset I would like to confess that I do not know as much as I would like to about the Lithuanians as the last pagan nation in Europe, nor do I understand every piece of evidence to a level where I could be satisfied once and for all. Definitive conclusions are hard to arrive at and frequently a reasonable assumption is all that we can aspire to achieve. Consequently, I will share a number of observations related to the art of politics employed by Lithuanian rulers when faced with the option of converting to either the Roman Catholic or Greek Orthodox faith. To begin with, it must be pointed out that when dealing with this topic we are primarily confronted with a form of doubledealing which is shrouded in the mists of time and is very poorly served by the written sources. We have to deal with strange phenomena which defy clear-cut explanations. On the one hand, we can observe solemn declarations indicating the truthfulness of the intentions of Lithuanian pagan rulers to embrace the Christian faith, on the other, we see their striking resourcefulness when retracting their words once the prospect of baptism came close to reality. What was the rationale behind this sort of political behaviour by the dukes Gediminas, Algirdas, Kęstutis, and even Jogaila? There is no straightforward answer. There are, however, different ways to approach this topic. I am not the first nor the last scholar to deal with this issue. It is undoubtedly a group effort to which I am merely providing my own contribution.

The use of ruse and deception in war and diplomacy, as well as the habit of cheating each other, goes back through the ages. ${ }^{7}$ Here I would like to make my contribution on the issue of misapprehension. Is it possible to write down a history of misapprehension and misunderstandings? What do I mean by misapprehension? I mean the failure to understand the underlying assumptions informing the way of thinking and the course of action on the part of a friend, ally, partner or enemy. Misapprehension as misreading intentions and goals. Misapprehension may be one-sided when only one side happens to be taken in. Misapprehension may be two-sided, or many-sided when both sides or a larger number of parties fail to understand each other correctly. In my opinion, different world-views in action are best in evidence in religious politics, regarding the issue of ecclesiastical unity and disunity. It is curious to note that what today are the self-evident

6 Delacroix-Besnier, Claudine: Les Dominicaines et la Chrétienté Grecque aux XIVee et XVe siècles. Collection de l'École Française de Rome 237. Roma 1997, p. 55. When compared to Western Europe, Eastern Europe may be regarded as a more tolerant region as far as interfaith relations are concerned, see BEREND, Nora: At the Gate of Christendom. Jews, Muslims and "Pagans" in Medieval Hungary, c. 1000-c. 1300. Cambridge 2001, pp. 52-53.

7 For different uses of deception by heroes and writers of Greek and Latin Antiquity see, for example, Ruses, secrets et mensonges chez les historiens grecs et latins. Actes du colloque tenu les $18-19$ septembre 2003. Edd. Hélène Olivier - Pascale Giovannelli-Jouanna - François Bérard. Université Jean Moulin Lyon 3. Lyon 2006. 
profound differences between, for example, the Latin and Greek understanding of sin, was not so evident historically, even though this involved fundamentally different anthropological conceptions. ${ }^{8}$ Of course, the ecclesiastical sphere is not the only one where different world-views clashed. The instances of the latter case are especially revealing and instructive when we have to deal with partners belonging to different mental worlds. For example, in 576 the Turkish khan, Tourxath, exploded with rage in front of the Byzantine envoys and used some exquisite gestures to hammer home his message:

"Are you not those Romans, who have ten tongues, but one deceit? ... As my ten fingers are
now in my mouth, so you use many tongues: with one you deceive me, with another the Avars,
my slaves. You flatter and deceive all peoples with the artfulness of your words and the treach-
ery of your thoughts, indifferent to those who fall headlong into misfortune, from which you
yourselves derive benefit." 9

A gulf of misapprehension lay between the Westerners and the Byzantines during the era of the Crusades. Jonathan Harris has provided an exemplary account of how different agendas sparked mutual misunderstanding and hatred between Latin and Greek Christians, which finally resulted in the sacking of Constantinople during the Fourth Crusade. ${ }^{10}$ A good example of completely different worlds is also provided by the correspondence of Pope Innocent IV (1243-1254) and the Mongol khan, Güyüg (1246-1248). The Holy Father sent him a complaint about the Mongol atrocities perpetrated in Eastern Europe and pleaded with him to return to his senses and receive the holy baptism. In response, the Great Khan frankly admitted that he simply did not understand what the pope was talking about and reciprocated by inviting the pope to come in person in an act of the express recognition of his submission to the universal rule of the Mongol khan. ${ }^{11}$ The Mongols had their own heavenly mandate to pursue. ${ }^{12}$

The case of Russia is also particularly revealing. The Russian principalities had been placed under Tatar rule for more than two centuries, and the rulers of Moscow proved

8 Livanos, Christopher: Greek Tradition and Latin Influence in the Work of George Scholarios: "Alone against all of Europe". Piscataway N.J. 2006, pp. 2 and 16-17.

9 Quoted after Овоlensky, Dimitri: The Byzantine Commonwealth: Eastern Europe, 500-1453. London 2000, p. 168. A description of the embassy is provided by Menander the Protector: Historici Graeci Minores. Vol. 2. Menander Protector et Agathias. Ed. Ludwig August Dindorf. Lipsiae 1871, pp. 86-87. For more on Byzantine statecraft and diplomacy see SHEPARD, Jonathan: Byzantine diplomacy, A.D. 800-1204. Means and ends. In: Byzantine Diplomacy. Papers from the Twenty-Fourth Spring Symposium of Byzantine Studies, Cambridge, March 1990. Edd. Jonathan Shepard - Simon Franklin. Aldershot 1992, pp. 41-71; LuTwaK, Edward N.: The Grand Strategy of the Byzantine Empire. Cambridge MA 2009; Kaldellis, Anthony: Did the Byzantine Empire have "ecumenical" or "universal" aspirations? In: Ancient States and Infrastructural Power: Europe, Asia, and America. Edd. Clifford Ando - Seth Richardson. Philadelphia 2017, pp. 272-300.

10 Harris, Jonathan: Byzantium and the Crusades. London - New York 2003, esp. pp. 127-143.

11 Luprian, Karl-Ernst: Die Beziehungen der Päpste zu islamischen und mongolischen Herrschern im 13. Jahrhundert anhand ihres Briefwechsels. Città del Vaticano 1981 (= Studi e testi 291), pp. 182-186 (the letter of Khan Güyüg is dated to 11-13 November 1246).

12 Jackson, Peter: The Mongols and the West, 1221-1410. Harlow 2005, p. 46 and pp. 89-90. 
to be extremely capable pupils of the Tatars. ${ }^{13}$ They possessed first-hand knowledge of how things were conducted in the world of the steppes. It was a world where alliances were easily changed and abandoned, where subservience was considered to be a personal affair with no long-term consequences. However, such an easy-going approach to politics was subverted once the Russians moved into the lands of the nomadic peoples of Eurasia. From then on, an alliance had to be understood as allegiance, while service had to be understood as permanent bondage and dependence. ${ }^{14}$ These rules were only applied to the victims of the Russian empire-building enterprise, while the Russians allowed themselves to enjoy the liberty of abrogating "eternal peace" agreements whenever they saw fit. One might say that Russia has remained a master in dissimulation and deception ever since. Why this was so and why, for example, Westerners have always tended to rely on stereotypes rather than on factual evidence in their dealings with Russia, has been very competently elucidated on by Alain Besançon in his study Sainte Russie..$^{15}$ These examples have been given in order to illustrate that cultural differences ran very deeply in the past and have a strong grip on the present, with no signs of them dying out any time in the future.

Fragmentary anecdotal evidence and a few references as to how representatives from different mental worlds interacted with each other serve as concrete instances whereby a history of misunderstandings and misapprehension across space and time may be explored and written down. My contention is that medieval Lithuanians also made some of the best contributions to this chapter of universal history.

\section{The common ground between the pagan Gediminas and the Greek Orthodox patriarch Joseph II of Constantinople}

It is useful to look at the example of Grand Duke Gediminas of Lithuania (1316-1341), who in 1322-1323 addressed six letters to the pope, the Hanseatic towns, and to Dominican and Franciscan friars. ${ }^{16}$ These letters represent an extraordinary historical source

13 The literature on this topic is very extensive, suffice here to mention Halperin, Charles J.: Russia and the Golden Horde. London 1987; Fennel, John L. I.: The Crisis of Medieval Russia. London 1983, pp. 108-121; Ostrowski, Donald: Muscovy and the Mongols: Cross Cultural Influences on the Steppe Frontier, 1304-1589. Cambridge 1998; Горский, Антон А.: Москва и Орда. Москва 2000.

14 For more on so-called steppe politics see KAPPeLer, Andreas: Rußland als Vielvölkerreich: Entstehung, Geschichte, Zerfall. München 1992, pp. 54-56; Kнодаrкоvsкy, Michael: Russia’s Steppe Frontier: The Making of a Colonial Empire, 1500-1800. Bloomington - Indianapolis 2002, esp. pp. 51-63; Neumann, Iver B. WIGEN, Einar: The Steppe Tradition in International Relations: Russians, Turks and European State Building, 4000 BCE-2017CE. Cambridge 2018.

15 Besançon, Alain: Sainte Russie. Paris 2012.

16 Chartularium Lithuaniae res gestas magni ducis Gedeminne illustrans. Gedimino laiškai. Ed. Stephen C. Rowell. Vilnius 2003, no. 14, pp. 38-41 (to Pope John XXII, summer 1322); no. 16, pp. $46-49$ (to all Christians, 25 January 1323); no. 17, p. 50 (to Dominican friars in Saxony, 26 May 1323); no. 18, p. 51 (to burghers of Saxony, 26 May 1323); no. 19, p. 52 (to Franciscan friars in Saxony, 26 May 1323); no. 20, p. 54 (again to Pope John XXII, May 1323 (?) ). Contents of the second letter of Gediminas to the pope are known as 
in the medieval history of Europe. ${ }^{17}$ This is because we have a pagan ruler engaging in dialogue with a Christian audience, a dialogue that was conducted not only by word of mouth, but also by the medium of the written word. The paganism of North Eastern Europe has been largely lost to posterity because of its exclusively oral nature. Christians had a huge advantage over their pagan opponents due to their ability to write manuscripts, which as we are supposed to know in this (eastern) part of Europe do not burn. Therefore, the letters of Gediminas represent a window of sorts into the mind of a pagan ruler. Much of the information contained in his letters pertained to bringing about peace between the pagan Lithuanians and their Christian neighbours. There was a great deal of attention focused on advertising the favourable conditions which would-be newcomers to Lithuania could enjoy. They were invited to come and prosper in this country: craftsmen, peasants, knights and religious people, with the exception of unsuitable clerics such as the Cistercians and, in particular, the Teutonic Knights. ${ }^{18}$ However, the key to Lithuania's peace and prosperity lay in the Lithuanian ruler and his subjects' acceptance of the baptism. Gediminas could not fail to see that this was a prerequisite for everything he seemed to be standing for. However, this central pillar for the whole visionary edifice was conveyed in allegorical expressions. Gediminas intimated to Pope John XXII (1316-1334) what he most wanted to hear, namely that all the Christian faithful should be subject to the paternal authority of the Bishop of Rome, to whom he was also ready to accord his filial obedience. ${ }^{19}$ The Grand Duke of Lithuania deplored the state of infidelity to which he had been consigned, not because of his own obstinacy, but because of the Teutonic Knights, who in their infinite maliciousness had caused his predecessor, King Mindaugas, and all his kingdom to turn away from the true faith. ${ }^{20}$ Finally, after listing the multiple atrocities committed by the Knights, Gediminas promised to obey the pope in the same manner as other Christian kings and declared his readiness "to receive the Catholic faith." ${ }^{21}$ Fidem catholicam recipere, yet the plain and simple word "baptism" remained unspoken, as if stuck halfway. ${ }^{22}$ When the Grand Duke addressed the citizenry of the Hanseatic League, he informed them that his letter to the pope concerned the matter of Church union, ${ }^{23}$ though quite different things could be understood by "Church union" (pro ecclesie Dei unione). Gediminas conveyed to the theologically astute Dominicans his wish to be invested with the best robe (stola prima). ${ }^{24}$

reflected in papal letters: ibidem, no. 28, p. 92 (Pope John XXII to King Charles VI of France, 7 November 1323); no. 41, pp. 132-136 (Pope John XXII to Grand Duke Gediminas of Lithuania, 1 June, 1324).

Rowell, Stephen C.: The letters of Gediminas: 'Gemachte Lüge?’ Notes on a controversy. Jahrbücher für Geschichte Osteuropas NS 41, 1993, pp. 321-360; Metraščiai ir kunigaikščiu laiškai. Senoji Lietuvos literatūra 4. Vilnius 1996.

Chartularium Lithuaniae, no. 16, pp. 46-48. 
The Franciscan friars were similarly informed about Gediminas' desire to be led to the fields of plenty together with other sheep..$^{25}$ All these expressions may serve as references to the impending baptism, though not necessarily. This in fact turned out to be the case when the matter came to a head during the visit of the envoys of the papal legates to Vilnius in November 1324. The report by these envoys is another extraordinary document. It provides a glimpse into the workings of grand ducal diplomacy at its best. The crucial point was the issue of the pagan ruler's baptism. As well-informed diplomats, the envoys proceeded cautiously, knowing full well that the whole issue was very delicately poised. After some introductory remarks, Gediminas interrupted them with a simple question asking whether they really knew what was written in his letter to the pope. They stated that everything the letter contained indicated his desire to be baptized. To make his point crystal clear, Gediminas said that he had not asked anybody to write about his baptism. After some investigation, it transpired that the Grand Duke was technically in the right. A Franciscan friar, Berthold, was made into a scapegoat because he was responsible for the confusion due to his misinterpretation of the words of the Grand Duke. All the Christians present at the court tried to come to his rescue by asserting that to be a son of obedience and to come to the fold of the Church means nothing other than baptism into the Church. The representative of the Grand Duke was not impressed by these finer points of Christian exegesis as to what it meant to be a spiritual son and have a spiritual father. Gediminas had his own understanding of what these things were supposed to signify. He had no difficulty whatsoever in acknowledging that he was ready to regard the Holy Father as "father" simply because the person known as Pope John XXII was older than himself. However, there was nothing special about such a relationship. It transpired that the Grand Duke was generally in the habit of treating older people with the same filial respect, while he would regard people of the same age as brothers, and younger ones as his sons. Gediminas was not alone or unique in this kind of wisdom. A case in point is another example which came somewhat later:

"I have determined to myself that if the pope should have precedence over me in years, I will view him as my father. But if he is equal to me in years, I will hold him as my brother. But if he should happen to be younger, I shall hold him as my son."26

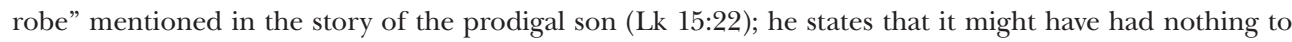
do with the practice of prima signatio, through which in earlier centuries pagans were admitted to have dealings with Christians without fully accepting the Christian faith, see Rowell, S. C.: Lithuania, p. 206. For more on prima signatio see FleTCHER, Richard: The Conversion of Europe. From Paganism to Christianity, 371-1386 AD. London 1998, p. 374.

25 Chartularium Lithuaniae, no. 21 p. 62 (26 May, 1323).

26 Les Mémoires du Grand Ecclésiarque de l'Église de Constantinople Sylvestre Syropoulos sur le Concile de Florence (1438-1439). Paris 1971, pp. 230-231. The English translation is quoted after Cunningham, Mary B.: Sylvester Syropoulos. The Author and His Outlook. In: Sylvester Syropoulos on Politics and Culture in the Fifteenth-Century Mediterranean. Themes and Problems in the Memoirs. Section IV. Edd. Fontini Kondyli - Vera Andriopoulou - Eirini Panou - Mary B. Cunningham. Farnham - Burlington 2014 (= Birmingham Byzantine and Ottoman Studies 16), p. 18. Translation into German is provided in Leben in Byzanz. Ein Lesebuch. Hg. v. Hans-Georg Beck. München - Zürich 1991, pp. 265-266. 
These were the words of Patriarch Joseph II of Constantinople (1416-1439). It was he who upon his arrival in Italy for the Council of Ferrara-Florence was greatly surprised to discover that during his audience with the pope he was expected to kiss his foot. The patriarch, incidentally, had the right to expect a more congenial reception from the pope due to the fact that in 1418 the newly elected pope, Martin V (1417-1431), had addressed him as his brother. ${ }^{27}$ Grand Duke Gediminas and Patriarch Joseph were completely contrasting characters, however, from this juxtaposition it becomes clear that they shared some common ground when they had to face the papacy. The origins of the sequence of respect due to the father, brother and son have not yet been discovered. Its roots may stretch as far back in time as the letter of the apostle Paul to Timothy: (1 Tim 5:1). This epistle was later commented on and the topic was reiterated a number of times by such dignitaries as St Basil the Great and St John Chrysostom. ${ }^{28}$ Hagiographical material also contains the appropriate injunction to show due respect to the father, brother, and son. This can be found in the Lives of St Efrem and St Porphyry of Gaza. ${ }^{29}$ The call to honour old and young people as father and brother respectively, is brought forward in the Pouchenie (Instruction) by Grand Duke Vladimir II Monomakh of Kiev (1113-1125). ${ }^{30}$ The Story of Dovmont/Daumantas (duke of Pskov, 1266-1299) has its hero address the men of Pskov using the terms of father and brother. ${ }^{31}$ Similar examples may be added as this topic seems to be widespread in a variety of literary sources. Even though it is unlikely that we will discover the exact source for Gediminas's ruse and resourcefulness in dealing with the papal envoys, the evidence gathered points in the direction of Eastern Christianity.

\section{The price of a Lithuanian soul}

Another battle of wits over the conversion of Lithuania was fought in the middle of the fourteenth century when the Lithuanian dukes found themselves in a difficult tug-of-war over the lands of Red Ruthenia with King Casimir of Poland (1333-1370) and King Louis I of Hungary (1342-1382). In 1349 King Casimir informed the pope of the willingness

27 LEIDL, August: Die Einheit der Kirchen auf den spätmittelalterlichen Konzilien von Konstanz bis Florenz. Paderborn 1966, pp. 18 and 92-93. For different accounts of the papal reception of Patriarch Joseph II supplied by Archbishop Dorotheos of Mytilene and the papal protonotary Andrew of Santacroce see PrICE, Richard: Precedence and papal primacy. In: Sylvester Syropoulos on Politics and Culture. Edd. Fontini Kondyli - Vera Andriopoulou et al., pp. 35-36.

28 Basilius Caesariensis: Moralia. In: Patrologiae cursus completus. Series Graeca. Vol. 31. Ed. Jean-Paul Migne (hereinafter PG). Paris 1857, col. 845; Joannes Chrysostomus: Homilia XIII in epistulam I ad Timotheum. In: PG. Vol. 62. Paris 1862, col. 566; Theodoretus: Interpretatio epistulae I ad Timotheum. In: PG. Vol. 82. Paris 1864, col. 816; Joannes Damascenus: Commentarii in epistulas Pauli. In: PG. Vol. 95. Paris 1864, col. 1012.

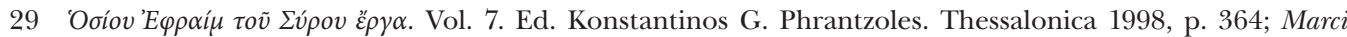
Diaconi vita Porphyrii episcopi Gazensis. Ed. Societatis Philologae Bonnensis sodales. Lipsiae 1895, p. 9.

30 Повесть временных лет. Vol. 1. Ed. Дмитрий С. Лихачев. Moskva - Leningrad 1950, p. 157.

31 ОхотниковА, Валентина И.: Повесть о Довмонте. Исследование и тексты. Leningrad 1985, p. 189. 
of Duke Kęstutis of Trakai (the brother and close collaborator of Grand Duke Algirdas of Lithuania, 1345-1377) and his kinsmen to accept the truth of the Catholic Faith. ${ }^{32}$ Pope Clemens VI (1342-1352) did all he could do to contribute to the success of the mission. On the one hand, he urged the Poles to do everything they could to safeguard the conversion of the pagans, on the other, the pope offered his protection and promised royal honours to the Lithuanian leaders if they accepted baptism. ${ }^{33}$ After some time, the Hungarian king, Louis I, came to the fore, and in the course of the joint HungarianPolish military campaign in the summer of 1351, Kęstutis appeared willing to resume negotiations over the baptism. He declared his readiness to be baptized along with his people if certain conditions were met. These included the good offices of the Hungarian king, through which a royal crown from the pope could be secured for a Lithuanian ruler. Hungarian assistance in getting rid of the danger posed to the Lithuanians by the Teutonic Knights and Tatars was also put on the table as a desideratum. ${ }^{34}$ A type of tripartite perpetual peace and a collaborative alliance between Hungary, Poland and Lithuania was being adumbrated. King Louis seemed willing to accede to these conditions. In turn, Kęstutis staged a most impressive oath-taking ritual by shedding the blood of a ruddy ox. After such a performance the Hungarians must have been convinced that something real would take place once Kęstutis was brought to the baptismal font in their capital city of Buda. All went well for a while until Kęstutis took advantage of the dead of the night to flee from the Christian camp, never to see the Hungarian king again.

A similar debacle happened to the Holy Roman Emperor and King Charles IV of Bohemia (1346-1378) some years later. In 1358 he issued a "golden bull" to the Lithuanian dukes, inviting them to be baptized. With regard to his generosity and open-handed approach,

32 Archivum Apostolicum Vaticanum (until October 2019 Archivum Secretum Vaticanum, hereinafter AAV), Registra Vaticana 62, f. 88r-88v; Vetera Monumenta Poloniae et Lithuaniae (hereinafter - VMPL). Ed. Augustin Theiner. Romae 1861, vol. I, no. 691, pp. 525-526 (16 September 1349); cf. KučInSKAS, Antanas: Kęstutis - Lietuviu tautos gynëjas. Marijampolè 1938 (n. ed. Vilnius 1988), pp. 124-127; BŁaszczyK, Grzegorz: Dzieje stosunków polsko-litewskich. Tom 1. Trudne początki. Poznań 1998, pp. 170-174.

33 AAV, Registra Vaticana 62, ff. 88v-89r; VMPL I, no. 692, p. 526 (16 September 1349); AAV, Registra Vaticana 62, f. 89r-89v; VMPL I, no. 693, pp. 526-527 (19 September 1349).

34 Most of the picturesque details of this Hungaro-Lithuanian interaction in the summer of 1351 are known only from one source: Chronicon Dubnicense cum codicibus Sambuci Acephalo et Vaticano, cronicisque Vindobonensi Picto et Budensi accurate collatum. Ed. Mátyás Flórián. Leipzig 1884, p. 161. See also RowELL, Stephen C.: A pagan's word. Lithuanian diplomatic procedure 1200-1385. Journal of Medieval History 18, 1992, pp. 152-155; BŁ_aszczyк, G.: Dzieje 1, pp. 153-154. The 1351 oath of Kęstutis and its subsequent breaking off became a widely known event to contemporaries and later generations of modern scholars alike. It was mentioned by Peter Suchenwirt and Petrarch, see Peter Suchenwirt's Werke aus dem vierzehnten Jahrhunderte. Ein Beytrag zur Zeit- und Sittengeschichte. Ed. Alois Primisser. Vienna 1827, p. 28 (IX, lines 140-143), p. 31 (X, lines 90-94) and p. 46 (XIV, lines 270-271). The relevant excerpts reproduced by Ernst Strehlke see in Beilage V. Aus Peter Suchenwirt, Heinrich dem Teichner und anderen deutschen Dichtern. In: Scriptores rerum Prussicarum. Bd. II. Hg. v. Theodor Hirsch - Max Töppen - Ernst Strehlke. Leipzig 1863, pp. 157-159. On Petrarch's knowledge of the oath of (probably) 1351, see Rowell, S. C.: A pagan's word, pp. 159-160. The oath may have had a meaning invalidating its express purpose. On this and the parallels in words and deeds taken from Roman antiquity and the Scripture (notably Gen 15:17 and Jer 34:18-20), see Ališauskas, Vytautas: Sakymas ir rašymas. Kultūros modeliu tvermè ir kaita Lietuvos Didžiojoje Kunigaikštystëje. Vilnius 2009, pp. 28-31. Judging from literary reactions, it is clear that the Christian audience took the oath as valid and regarded its breaking as perjury. 
the Bohemian king's proposals equalled those of King Louis. ${ }^{35}$ In response, one of the Lithuanian dukes (most probably the same Kęstutis) travelled as far as Nuremburg to pay a visit to King Charles. ${ }^{36}$ Now it was the turn of Charles to send an embassy to Lithuania. His authority was strong enough to make the Teutonic Knights provide logistical support to the embassy headed by the Archbishop of Prague, Arnošt of Pardubice (1344-1364). Once the embassy arrived in Lithuania it must have received promises that the Lithuanian dukes would arrive in Wrocław (Breslau) in Christmas 1358 to undergo baptism, sponsored by Emperor Charles IV himself. The Emperor and his entourage arrived in Wroclaw on time. ${ }^{37}$ However, instead of welcoming the pagans they were made privy to brazenly idiosyncratic demands. The Lithuanians now wanted the Teutonic Order to be moved to the steppes of present-day Ukraine and Russia to do battle with the Tatars. They also wanted exclusive rights to the lands of All Rus' recognized by the Emperor and the Teutonic Order. ${ }^{38}$ Such behaviour coupled with such outrageous demands must have left an indelible impression on all parties concerned. ${ }^{39}$

\section{A Greek Orthodox option?}

In contrast to the number of attempts to have the rulers of Lithuania baptized in the Latin rite, there are virtually no examples of their possible conversion to the Greek Orthodox faith. There is only one direct reference to such a possibility in the work of the Byzantine historian Nikephoras Gregoras (c. 1290-1360). However, the problem with

35 Preußisches Urkundenbuch. Politische Abtheilung. Bd. V.2. 1357-1361. Hg. v. Klaus Conrad. Marburg 1973, no. 642, pp. 361-362 (21 April 1358). Grundmann, Herbert: Das Schreiben Kaiser Karls IV. an die heidnischen Litauer-Fürsten 1358. Folia Diplomatica 1, 1971, p. 92. The most exhaustive diplomatic investigation of this bull is provided by KARWASIŃSKA, Jadwiga: Ztote bulle Karola IV w sprawie chrztu Litwy. In: eadem: Wybór pism. Źródła archiwalne. Warszawa 1998, pp. 178-196; originally published in Cultus et cognitio. Studia z dziejów średniowiecznej kultury. Edd. Stefan K. Kuczyński et al. Warszawa 1976, pp. 233-249. For the metapolitical concerns aimed at bringing closer to salvation the world and its rulers as an overriding motive in this appeal of Charles IV, see SEIBT, Ferdinand: Karl IV. Ein Kaiser in Europa 1346-1378. Münich 1978, pp. 380-381.

36 Chronica Heinrici Surdi de Selbach. In: Monumenta Germaniae Historica. SRG NS 1. Hg. v. Harry Bresslau. Berlin 1922, pp. 112-113.

37 Conrad, Klaus: Litauen, der Deutsche Orden und Karl IV. 1352-1360. Zeitschrift für Ostforschung 21, 1972 , pp. 21-24. See also VyskočIL, Jan Kapistrán: Arnošt Pardubic a jeho doba. Praha 1947, p. 503. A new biography has recently been written by Hledíková, Zdeňka: Arnošt z Pardubic. Arcibiskup, zakladatel a rádce. Praha 2008.

38 On the Lithuanian claims to "all of Russia" see PAszkiewicz, H.: Poczatki, p. 250. It may be noted that this claim coincided in time with attempts on the part of Lithuanian-sponsored Metropolitan Roman to extend his jurisdictional power over territories of All Rus' forming the metropolitanate of Kiev. On the activities of Metropolitan Roman see Meyendorff, John: Alexis and Roman. A study in Byzantino-Russian relations (1352-1354). Byzantinoslavica 28, 1967, pp. 278-288. Even though the origins of Lithuanian imperial claims deserve a special study, it is very likely now that the framework of the Rus'ian ecclesiastical structure provided a basis for the very notion of omnis Russia.

KuČINSKas, A.: Kęstutis, pp. 132-137. 
his story is that to a great extent it represents an exercise in wishful thinking. ${ }^{40}$ In this regard he was not alone as there are more indications that the Greek Orthodox leaders hoped that Lithuanians might one day become Greek Orthodox believers. ${ }^{41}$ However, these hopes must not be taken as indications on the part of Lithuanian rulers that they wished to become Orthodox Christians. At this point we should not be afraid to express some surprise. On the one hand, we have a number of negotiations where the eventual baptism of the Lithuanian rulers was on display for all to see. On the other hand, there is a virtual absence of anything like that with regard to Greek Orthodoxy, even though Lithuanian rulers were much more deeply involved in the Rus'ian affairs in general than was the case with their neighbours on the Western front. Therefore, even though one may say that pagan Lithuania was placed between East and West, the Lithuanians' behaviour towards Latin and Greek Christians was quite different. That is why the position of pagan Lithuania can hardly be viewed as the result of a consciously pursued policy of balancing between East and West, as has been described by Michael Giedroyć in his masterful articles published in the 1980 s. $^{42}$ In my view, the position of pagan Lithuania vis-àvis East and West was idiosyncratic rather than balanced, which is why I have described it as "going East, facing West." 43

It would be wonderful if a historian could take the vantage point of an ideal observer and relate clearly what is what and who is who, while it would be no less fine if a historian could re-enact the past experiences of Lithuanian dukes and nobles along the lines suggested by Robin G. Collingwood. However, as there is very little written evidence left, and most of it is not from the Lithuanian side, any attempt to understand the actions of the Lithuanian dukes will inevitably contain a large amount of speculation. There is no other way around this problem than to subject our own "historical imagination" to the checks and balances of historical research. With these caveats in mind, I would like to proceed to further considerations.

40 Baronas, D. - Rowell, S. C.: The Conversion, pp. 166-168.

41 Paszkiewicz, H.: Poczatki, p. 251 and p. 276. See also Preiser-Kapeller, Johannes: "Konfessionswechsel" als Drohung. Beobachtungen zum Aufstieg des Kyprianos zum Metropoliten von Kiev und Litauen (1375) im Kontext der Politik des Patriarchats von Konstantinopel an Kontaktzonen zur Westkirche im 13. und. 14. Jahrhundert. In: Church Union and Crusading in the Fourteenth and Fifteenth Centuries. Edd. Christian Gastgeber - Pop Ioan-Aurel - Oliver Jens Schmidt - Alexandru Simon. Cluj-Napoca 2009, pp. 253-278. For the celebrated 1371 letter (pittakion) of Grand Duke Algirdas in which he demanded from the patriarch of Constantinople a new metropolitan for his domains and those of his allies see Беспалов, Роман А.: О письме Ольгерда патриарху Филофею. Древняя Русь. Вопросы медиевистики № 2 (60), 2015, pp. 49-62. For the context of this pittakion from the point of view of diplomatics see HinTERBERGER, Martin: Les relations diplomatiques entre Constantinople et la Russie au XIV e siècle. Les lettres patriarcales, les envoyés et le langage diplomatique. In: Byzance et le monde extérieur. Contacts, relations, échanges. Ed. Michel Balard - Élisabeth Malamut Jean-Michel Spieser. Paris 2005, pp. 123-134.

42 Giedroyć, Michael: The arrival of Christianity in Lithuania. Early contacts (thirteenth century). Oxford Slavonic Papers NS 18, 1985, pp. 1-30; idem: The arrival of Christianity in Lithuania. Between Rome and Byzantium (1281-1341). Oxford Slavonic Papers NS 20, 1987, pp. 1-33; idem: The arrival of Christianity in Lithuania. Baptism and survival (1341-1387). Oxford Slavonic Papers NS 22, 1989, pp. 34-57.

Baronas, D. - Rowell, S. C.: The Conversion, pp. 149-174. 


\section{Lifestyle and great politics}

There is a certain danger posed by the wisdom of hindsight and it is easy to assume that the baptism of the Lithuanian dukes was a forgone conclusion. It is not difficult to list the advantages that would benefit Lithuania as a result of the eventual conversion of its rulers and large population to either Latin or Greek Christianity. However, we may ask whether economic prosperity was viewed by the Lithuanian rulers as being directly related to their acceptance of Latin baptism. Was their war with the Teutonic Order such a large issue that they were ready to submit themselves to baptism as the price for obtaining peace? Did the dukes such as Gediminas, Algirdas and Kęstutis want to be subject to the demanding lifestyle of Christian rulers and to have the Christian clergy by their side, who would dictate the regime of penance and fasting and much more? The appeal or aversion to one or other course of action must have depended first of all on the system of values and world-view of particular dukes and their milieu. That is why I think emphasis must be placed on such a neutral category as lifestyle. I imagine that Gediminas, Algirdas and Kęstutis must have been quite happy with their daily routine, consisting of military campaigns, hunting and feasting. This daily routine was probably at the basis of what historians see as a political programme, whether this was the modernization of the Lithuanian economy or defending their country and so on. In the fourteenth century, the Lithuanian dukes had to deal with inherited problems such as the Teutonic Order, and face a series of emergencies that they coped with quite successfully, as can be seen from the course of action taken by Gediminas in the 1320s. No matter what gullible Westerners might be promised, Realpolitik as understood by the ruling class of Lithuania was the order of the day. It was not out of step with the international developments of the time, especially if we pay closer attention to the eastern aspect of the Lithuanian saga. The crux of the matter is that the Lithuanian Realpolitik could mean two things at once. Viewed from a western Catholic point of view, the paganism of Lithuania made this country a legitimate target for Teutonic-style crusades. Viewed from the point of view of politics in Eastern Europe, the Lithuanian non-commitment to the Roman Catholic cause served as a safety-valve for Lithuania's dealings with the Golden Horde and Rus'ian principalities. The conditions they inherited were accepted for quite a long time, though this did not mean they were immutable, and once people with a different mindset came to power in Lithuania, a change was bound to happen.

Therefore, a warrior lifestyle should not be regarded as the ultimate goal for each and every Lithuanian pagan prince and his men around him. The ease by which the Christian faith in its Latin version was finally introduced to Lithuania in 1387 demonstrates that preferences in lifestyle had changed. And this was a matter that affected the younger members of the Gediminid dynasty and their entourage. In this case a particularly instructive example is that of Jogaila, also known as Jagiełł, the future Polish king Władysław II (1386-1434). It is worth drawing attention to his extraordinary ability to make friends. It is known that he entered into a friendly relationship with the Franciscan Pietro da Candia (Petros Philargis, the future anti-Pope Alexander V, 1409-1410), when 
the latter happened to visit Lithuania during the rule of Jogaila's pagan father Algirdas. ${ }^{44}$ We know that Jogaila maintained friendly relations with Metropolitan Cyprian of Kiev and All Rus' ${ }^{45}$ It is likely that the roots of their friendship reach as far back as the time of Cyprian's visit to Lithuania in $1373 / 1374 .{ }^{46}$ These friendships served Jogaila well, but now they are important as indicators of Jogaila's more intensive interest in the outside world, unlike his father Algirdas or his uncle Kęstutis. Like his pagan predecessors, Jogaila remained an ardent hunter, but he also embraced the practicalities of being a Christian ruler. His lifestyle was different from early on and his conversion to Latin Christianity in 1386 was not a rash decision taken solely in a bid to acquire the Polish throne. His lifestyle is again responsible for the image of pursuing a programme when there was none. Jogaila had to deal with matters he had inherited, he faced a number of emergencies and reacted to unexpected opportunities. Finally in 1387, he introduced the Roman Catholic faith into Lithuania and by doing so went past the point of no return. Had the preferences of the ruling class and events in international politics been different, we would have had to deal not only with another story, but with quite another history. There was nothing predetermined to prevent pagan Lithuanians from remaining that way for several more generations or converting to Greek Orthodoxy, or perhaps even to Islam. In retrospect, we might say that familiarity with the Roman Catholic world was of overriding importance. However, had Jogaila and his entourage decided to throw in their lot with Greek Orthodox world, then we would have been compelled to draw an equally plausible conclusion that the pull of Eastern Christianity proved stronger. It makes sense to say that with the conversion of Lithuania "medieval Latin Christendom was at last formally complete," as Richard A. Fletcher stated. ${ }^{47}$ However, this did not mark the end of the history of the expansion of Christianity into Northern and Eastern Europe, where pagan peoples survived close to the Ural Mountains and along the River Volga well into the early modern era. However, if a nation is described as a stateorganized society, then the Lithuanians could indeed be viewed as the last pagan nation in Europe. However, they were not the last pagan people in Europe, let alone the wider world, instead they appear as Europe's eleventh-hour Christians.

44 Ibidem, p. 219.

45 Papadakis, Aristeides - Meyendorff, John: The Christian East and the Rise of the Papacy. The Church 10711453 A. D. Crestwood 1994, p. 344.

46 Chodynicki, Kazimierz: Kościót prawostawny a Rzeczpospolita Polska. Zarys historyczny 1370-1632. Warszawa 1934, p. 20; Овоlensky, Dimitri: A Philorhomaios anthropos. Metropolitan Cyprian of Kiev and All Russia (1375-1406). Dumbarton Oaks Papers 32, 1978, p. 86.

47 Fletcher, R.: The Conversion, p. 507. 


\section{Jednání v dobré víře a Realpolitik. Na cestě k porozumění politice litevských vládců ve 14. století}

Článek se zabývá otázkami spojenými s litevskou konverzí ke křestanství ve 14. století. Soustřed’uje se na hodnocení politiky, v níž dominovaly záměrné oklamávání a zároveň nepředvídatelné události. Téma oklamávání a nedorozumění, které se představuje v širším kontextu, ukazuje, že pluralita rozdílných představ o světě dlouhodobě ovlivňovala průběh politického jednání, jehož předpoklady nebyly jednajícím stranám vždy zřejmé. Případ pohanské Litvy skýtá zajímavou možnost pochopit, že orální kultura nebyla zdaleka vždy v méněcenném postavení vůči kultuře písemné. Toto platí zejména pro komunikaci mezi velkoknížetem Gediminem (1316-1341) a představiteli papežství v letech 1323-1324. Jednání litevských vládců s evropskými partnery na panovnických trůnech v polovině a ve druhé polovině 14. století ukazují, že pro ně konverze ke křestanství, at v podobě latinské či pravoslavné, nebyla prvořadým zájmem. Zděděné zvyky po předcích a vojenský způsob života byly pro litevská knížata dostatečným důvodem k setrvávání v pohanství. K nezvratné změně došlo, až když se k moci dostali vládci s jiným vnímáním světa a roku 1387 lehce uskutečnili to, co nesvedlo mnoho vojenských srážek a mnohá vyjednávání. Př́sně vzato Litevci nebyli posledním pohanským etnikem Evropy, ale z hlediska formování národa a státu byli posledními, kdo se připojili do křestanské rodiny evropských národů. 